DOI: 10.19195/0137-1150.168.21

Data przesłania artykułu: 15.09.2017

Data akceptacji artykułu: 2.01.2018

\author{
JANA VRAJOVÁ
}

Univerzita Palackého v Olomouci, Republika Czeska

\title{
Podoby smrti v básnických textech Josefa Svatopluka Machara
}

\begin{abstract}
Poněvadž mi žádná kniha nedovedla dosud říci, co je to Ř́m, pokusil jsem se napsat si ji. Byl jsem tam za Antikou a našel nádherné bílé kosti její a viděl velkolepý hrob její. A na hrobě tom viděl jsem ležet v umírání zchátralého a vyvanulého vraha jejího ${ }^{1}$.
\end{abstract}

Když v roce 1882 otiskl Josef Svatopluk Machar ve „Světozoru“ svou první báseň Zimní kosmická píseň, málokdo mohl po jejím přečtení očekávat, že do literatury vstupuje osobnost, která bude mít ambice dotýkat se velkých témat a jejich pomocí se pokoušet přetvářet kulturní dobové paradigma. Jednalo se totiž spíše o hříčku než o vážně míněný básnický počin; o variaci na tvorbu autorem obdivovaného Jana Nerudy a k němu se hlásící již aluzí na jeho práci v titulu básně. Ve svém př́́spěvku chci ukázat, jak s jedním z velkých uměleckých témat — smrtí - Machar ve svých zralých textech pracoval. Poukážu na dvě podoby smrti: smrt jako hrdou alternativu porobenému životu a smrt jako koncept historizující poezie.

\section{Hrdá smrt}

Tematizace smrti se objevila již v první sbírce veršů Confiteor (1887). Sice zatím víceméně nahodile, spontánně a nepříliš kompozičně promyšleně, ale

${ }^{1}$ J. S. Machar, z dedikace knihy Řím Růženě Svobodové, [in:] idem, Řím, Praha 1921, s. 3. 
přesto $\mathrm{v}$ některých rysech pro budoucí macharovskou poetiku typicky. V úvodní básni sbírky nesoucí název Vstupní dialog, jejíž tematickou dominantou je otázka charakteru poezie, byla metafora smrti básnictví čtenáři nabídnuta jako lepší alternativa života v porobě, otroctví. Je možno jí rozumět pouze v souvislosti s doznívajícími dobovými diskusemi o charakter česky psané literatury. Zdeněk Pešat v takzvaných akademických dějinách české literatury při charakterizaci Macharových prvních tří sbírek Confiteor (1887), Bez názvu (1889) a Třetí kniha lyriky (1892) napsal, že se v nich básník ,zříká ideálů dosavadní poezie, odmítá svými verši sloužit společnosti““2 . Tato teze je následující citací jasně doložitelná. „Tož, poezie, zhyň, než býti děvkou robnou / za ten chléb hanebný ve službách kramáře, / tou, jež jen v neděli smí vzít svou sukni zdobnou / a chvilku pobýt u svých bohů oltáŕe! ‘33.

Hrdá smrt, smrt smysluplnější než život, to je motiv, s nímž se setkáváme u Machara opakovaně - již zcela záměrně s ním pracoval ve sbírce $V$ záři helénského slunce (1906), v níž vědomým návratem k antickému dědictví a latentním přeznačováním křestanských hodnot směřoval k zdůraznění nejvyšší ctnosti antického světa: virtus. Ta v sobě zahrnovala vlastnosti jako síla, odvaha, statečnost, čestnost, hrdost, ale i síla ducha, mravní síla. Právě s respektem k této superctnosti mohla v básni Posel postava matky padlého hrdiny jako reakci na zprávu o bitvě u Thermopyl pronést: „Já smrtelného zrodila jsem syna: / ó bozi věční, ted’ jsem matkou štastnou“4 . Avšak posel, který jediný bitvu přežil, aby o ní mohl podat svědectví, si v Macharově básni zoufá:

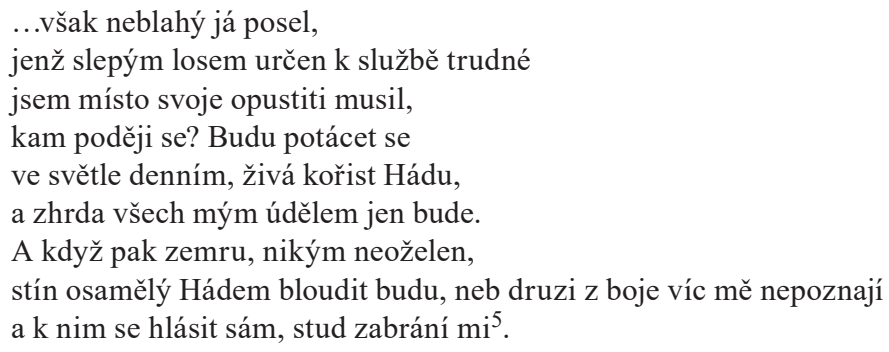

V souvislosti s básní Posel naznačil Ferdinand Stiebitz v roce 1934, že se Machar nevymanil z pozic novohumanistické ideologie, pro niž antika byla jen konstrukcí a neodpovídala mnohotvárné skutečnosti:

Machar tkví svým obrazem o záři helénského slunce a vším, co tak symbolizuje, úplně v idealizujícím novohumanismu. [...] Hérodotos vypráví o jednom Spart’anovi, jenž se vyhnul poslednímu boje u Thermopyl; tak zůstal jediný ze slavných tří set naživu, vrátil se do Sparty a byl stižen bezectím. Byl to zbabělec. Machara podnítil ten př́iběh k známé básni Posel ${ }^{6}$.

${ }^{2}$ Dějiny české literatury III, ed. M. Pohorský, Praha 1959, s. 507.

3 J. S. Machar, Confiteor, Praha 1887, s. 10.

4 J. S. Machar, V záři helénského slunce, Praha 1906, s. 70.

5 Ibidem, s. 71.

${ }^{6}$ F. Stiebitz, Macharova antika, „Naše věda“ 1934, č. 9 (15), s. 209-214. 
Variantou hrdé smrti je motiv smrti jako vysvobození z nešt’astného života. Ten nalézáme např́klad v epické básni Umíráni ze sbírky Zde by měly kvést rưže (1894). V ní nemocná hrdinka rekapituluje svůj život. Vzpomíná na manželskou lásku, jež vyprchala, manželovu nevěru, která toho byla důsledkem, matčinu radu, že partnerské soužití pojí zvyk, nikoli láska, i to, jak svůj cit upřela ke kočce. Když jí služka oznámí, že zvíře pošlo, poručí žena spálit usušenou svatební kytici a cítí se být připravena na smrt, protože ji již nic nepoutá k životu.

Ve sbírce Zde by mély kvést růže Machar tematizoval i podoby násilné smrti: sebevraždu, vraždu i popravu. Báseň Marie Wiltová byla inspirována zprávou v novinách o sebevraždě slavné operní zpěvačky a Machar ji využil ke kritice maloměšt'ácké touhy po senzaci, ale zejména ke zdůraznění tragiky životních osudů výjimečným talentem obdařených lidí. Romantické představě výjimečnosti umělce dává antický nátěr, když zmiňuje Osud či Fatum, jenž rozhoduje o lidském konci, nebo když vytváŕí paralelu mezi osudem slavné zpěvačky a osudem antické Sapfó. Umělkyně je charakterizována jako ta, která je obdařena géniem a božskou jiskrou, což odpovídá romantické představě o pozici umělce ve společnosti (Machar byl ostatně Xaverem Šaldou označen za ,psychologa romantismu“): „Z té ženy s nízkým plochým čelem, / z vídeňské zelináŕky tělem / génius zářil v lesku skvělém / a božská velkost splývala“7. Závěrečná strofa je nepřímou metafyzickou výčitkou Osudu, jenž obdařuje tíží talentu, bolestí nadání (Machar Fatem důsledně nahrazoval místa, kde by se $\mathrm{v}$ textech $\mathrm{v}$ návaznosti na křestanskou tradici apostrofoval bůh). „Ne, nedopadlo její tělo / na kámen dvorku; ono hřmělo / ve vyčítavém chropotu / kams jinam. V líc geniu svému, / v líc tomu božství ukrutnému, / své slávě klnulo i jemu / i nežitému životu“8.

Básně Červené střevíčky a $Z$ vlaku jsou epickými básněmi rozpracovávajícími téma popravy dvou vrahů: v Červených strevíčkách je vrahem žena, v básni $Z$ vlaku — muž. Zatímco v básni $Z$ vlaku je dobře čitelná lineárně kauzální linie (prchlivý mladík se bezhlavě zamiluje a ve chvíli, kdy zastihne svou milou při milostných hrátkách s jiným, svého soka v lásce zabije), v Červených střevičkách není motivace k brutální vraždě manžela implicite čtenáři sdělena. Počítá se s jeho schopností rekonstruovat možnou podobu manželského soužití na základě znalosti rodinné situace, již má objasnit informace, že Rosa vysekala sekerou z manželovy mrtvoly srdce a jako šílená po něm radostí šlapala. Báseň $Z$ vlaku je vystavěna na principech realistické techné, intertextově odkazuje k Nerudovým Písním kosmickým (1878) (př́ímá citace „Ach což ta láska mateřská / přes časy, přes hrob hoří, / neumrazíš ji na horách, / neuhasíš ji v moři“9) a je jednoznačně interpretovatelná skrze téma mateřské lásky, které neustává ani ve chvíli, kdy je dítě společností odsouzeno $\mathrm{k}$ trestu smrti. Naproti tomu Červené střevićcky odkazují vyprávěním mordu ponocným při dračkách až $\mathrm{k}$ tradici kramářských písní

\footnotetext{
7 J. S. Machar, Zde by mély kvést růže, Praha 2012, s. 192.

${ }^{8}$ Ibidem, s. 195.

${ }^{9}$ Ibidem, s. 202.
} 
a nejednoznačnost motivace zápletky směřuje za příběh: ke kritice církve. Soudci si totiž nevěděli rady s podivnou vraždou bez zjevného motivu ani s podivnou vražedkyní - krásnou křehkou mladou ženou s pomněnkovýma očima, která nic nezapírá a do posledního detailu vše vylíčí bez náznaku smutku — proto se obrátili o radu k panu děkanovi. Ten jim naznačil, že by žena mohla být ve spolku s d'áblem a posteskl si, jaká to byla chyba, že „císař nebožtík dal odstraniti právo útrpné ze soudních síní“10. Církev se tedy dle Machara podílela na tmářství, zastírání reálného stavu mnohých soudobých manželských svazků a místo pochopení pro utrpení ženy ji ještě více ponižovala a zostuzovala. Svoboda a radost z červených střevíčků, v nichž šla Rosa na popravu, pak v tomto kontextu nemohla být v Macharově fikčním světě přihlížejícímu konvencím podléhajícímu člověku srozumitelná.

Hrdá smrt, smrt jako cesta k finální svobodě je však v epilogu sbírky Zde by měly kvést růže v básni Nad mou malou dcerou relativizována tváŕí v tvár̆ počínajícímu životu dítěte. V něm se objevuje vítězství přirozené, pudové touhy po životě, ústící v závěrečnou prosbu: „Bud’ kdokoli, ty nezjevený, / bud’ kdekoli tvůj věčný byt — / je v žití tom tak málo ceny,/ však nech to moje dítě žít!“"11. Ve veršovaném románu Magdalena (1894), vydaném v témže roce jako Zde by měly kvést růže, též zvítězí touha po životě, byt' realisticky bolestně nedokonalém, nad zvažovanou sebevraždou (ve vnitřním dialogu postavy v sémanticky exponovaném místě textu zaznívá: „Žít, ach žít jen! / Nelze umřít, není síly, / není ani viny žádné!“"12). V Magdaleně se objevuje odmítnutí volby dobrovolné smrti kvůli ideálu či jiné hodnotě (zvažovaná možnost pomsty Lucy Jiřímu). O několik let později začal Machar v Jedu z Judey (1906) programově ironizovat odhodlání zemřít za ideu na př́kladech křestanských mučedníků. V Magdaleně položil základy nároku žít bez pomocí ideálů — tedy i bez Boha.

\section{Smrt jako koncept}

Vliv Friedricha Nietzscheho na Macharovo dílo bývá zmiňován většinou bez detailní analýzy jeho textů, spíše je jeho filozofie zdůrazňována jako silná inspirace procházející modernistickým myšlením mnoha literátů přelomu stoletín ${ }^{13}$. Do českého kulturního prostoru Nietzscheho myšlenky přinášel zejména František Václav Krejčí (v roce 1896 měl o něm dvě přednášky v Jednotě filozofické). Intenzivně bylo Nietzscheho dílo recipováno $\mathrm{v}$ roce 1900 , tedy $\mathrm{v}$ roce jeho smrti. Právě F. V. Krejčí tehdy publikoval v „Rozhledech“ prvního čísla desátého ročníku Nietzschův nekrolog, v němž připomněl jeho ,nesmírný vliv" a zdůraznil, že Nietzsche dal generaci 90. let „především bezmeznou víru v život ${ }^{\text {"14. }}$. Machar

\footnotetext{
10 Ibidem, s. 229.

11 Ibidem, s. 245.

12 J. S. Machar, Magdalena, Praha 1926, s. 218.

13 A. Novák, Bedřich Nietzsche v Čechách, „Národní listy“ 21.4.1912.

14 F. V. Krejčí, Nietzsche, „Rozhledy“ 1900, č. 1, s. 1.
} 
sám Nietzschův vliv na svou tvorbu odmítal, tvrdil, že „z něj zná jen málo“15, když ovšem připomeneme jinou pasáž z Krejčího nekrologu, v níž charakterizuje Nietzscheho filozofii jako „nové náboženství“ nebo „moderní náhradu za mrtvé náboženské víry“ či připomeneme překlad úryvku Nietzscheho v „Moderní revue“ (1894-1925) pod názvem Morálka jako protiprirozenost, vidíme, jak blízko se myšlenkově Machar Nietzschemu zejména v cyklu Svědomím věku (1906) pohyboval. Za zásadní považujeme přijetí konceptu „smrti Boha“ (křest’anského), jenž je myšlenkovou dominantou Jedu z Judey, ale i dalších svazků cyklu. Zároveň však v návaznosti na výše řečené konstatujeme, že již v prvním období tvorby (Confiteor), tedy v době, kdy Nietzscheho texty u nás ještě nebyly recipovány (česká veřejnost se s nimi postupně seznamovala až v 90 . letech ${ }^{16}$ ), můžeme v Macharově poezii sledovat motivy směřující ke konceptu mrtvého boha (překonaného náboženství), jejž plně rozvinul ve sbírkách $V$ záři helénského slunce a Jed z Judey. Je patrný např́klad v práci s prostorem hřbitova. Ten Machar již v Confiteoru využíval v souvislosti s odkazem na křestanství, na Krista, kterého tematizoval většinou na křiži (tedy popravčím nástroji) umístěném právě do prostoru hřbitova. S tím souvisejí prrívlastky, kterými básník postavu Krista obdařil: sestárlý, opuštěný, opletený pavučinou. Kříž pak je sešlý, omšelý, zakrytý keřem, stojí u hřbitovní zdi. Jedna z básní nese přímo název Kř̌ž a básník v ní popisuje osud kříže, který byl pro své stáří odstraněn z kostela a nahrazen novým. Autor v ní až blasfemicky apostrofuje Krista: „Tys, Kriste, sestárl, a ruka umná / nového boha dala ve chrám náš, / kol něho pocta se ted' vznáší šumná / a ty v exilu smutném dokonáš $[\ldots]^{\text {“17 }}$.

Macharova historizující poezie sbírek Svědomi věků je ve své podstatě ahistorická, mířila do autorovy současnosti, měla didaktizující tendenci ${ }^{18}$. Aktualizace antické látky byla podřízena potřebě kritiky soudobých poměrů ve společnosti i církvi. Koncept smrti antického člověka užívajícího si št’astného života, který byl otráven jedem z Judey — křest’anstvím — na Macharovy čtenáře fungoval, nebot' těžil z dobové krize hodnot, potřeby jejich revize, stejně jako potřeby revize církve. Podle Machara křest’anství nepřirozeně vyzdvihlo slabé, čímž přispělo ke zkrocení přirozených pudů člověka. Jako Nietzscheho Dionýsos reprezentoval „vůli k moci“, tak Macharovy postavy (ty, které měly být hodny následování silní jedinci vědomí si vlastní hodnoty, kteří nemají strach ze smrti) reprezentova-

15, ,[...] došel jsem k poučce starého Goetha, že největším štěstím člověka je osobnost, individualita, nerozpoltěný, celistvý člověk a začal jsem jej hledat. A našel jej v antice. A našel jsem, že tuto antickou nerozpoltěnou osobnost zabilo křest’anství. A řekl jsem to. Nebyl to Nietzsche, znám od něj dosud tuze málo, ale došel jsem sám k tomu cestou, jak jsem ji tuto popsal. Vznikly knihy V zárí helénského slunce, Jed z Judey, Řim [...]" - J. S. Machar, Třicet roků, Praha 1919, s. 138.

16 J. Zouhar, K rozšírení Nietzschovy filozofie u nás na přelomu století, [in:] Sborník prací filozofické fakulty brněnské univerzity, B 39, Masarykova univerzita, Brno 1992.

17 J. S. Machar, Confiteor..., s. 160.

18 Viz např́iklad A. Procházka (pod pseudonymem Martin Laton), Didaktická poesie / poznámky a námitky, „Moderní revue“ 1907, č. 7, s. 315. 
li „vưli k životu“. Autor záměrně polarizoval prožívání již zmíněné „hrdé smrti“ u postav, jež zasadil do antické tradice, a postav reprezentujících křest’anský svět, kteří sice také působí dojmem, že strach ze smrti necítí, ten je ovšem podle autora potlačen fanatickou vírou či davovou hysterií (básně V katakombách, Ad bestias!, Křestanka, Zelené oči, Poustevnici, Simeon Stylites, Mučedník).

Machar našel svůj způsob uměleckého vyjádření v poetice vycházející z nerudovské tradice. Za prostřredky ironie křest’anství mu sloužila ustálená slovní spojení běžná mezi křest’any, citáty z bible, ale i patetický styl kazatelů. „Den soudu přijde, chvíle účtování! / Aj, pastýř dobrý bude dávit tygry / a vlkům vyrve srdce plné zlosti. / Hospodáŕ vyjde na mlat oddělovat /pšenici od plev. Zem, zahrada hř́íchů, /se zachví hrůzou, [...] / Beránek čistý ohlásil svůj př́ichod / a ženich duší našich svatbu svoji“ (V katakombách) ${ }^{19}$. V závěru básně Kynik (V záři helénského slunce, v prvním vydání se nevyskytuje, byla do sbírky přidána až v pozdějších vydáních), jež je ironickou oslavou chudoby a smíchu, se postava kynika Menippa vysmívá soudobé představě smrti. $\mathrm{K}$ antické kulturní tradici patřila postava převozníka Chárona jako toho, kdo umírající převáží na druhý břeh Acheronu, do podsvětní říše stínů. Aby mu mohli zemřelí za tuto službu zaplatit, vkládala se jim posmrtně do úst drobná mince - obolos. Menippos je však smířen s tím, že tento obolos u sebe mít nebude, nebot', jaktěživ ho neměl v životě“", a chystá se převozníka obelstít návrhem, že se vrátí zpět do říše živých, pokud by na platbě trval. Báseň by se dala hyperbolicky označit za Macharovo tvůrčí krédo, Menippův smích je totiž smíchem nad lidskou malostí (smíchem ,z rozšafných a moudrých občanů, / již o blaho města se starají, / složivše kůži čela do vrásek, / by označili vážnost práce své' ${ }^{\prime 20}$ ), ateisticky blasfemickým smíchem nad těmi, kdo potřebují k životu víru v bohy / Boha (,smích z kněze, který vážně rozkročen / mečící ovce krutě zabíjí / a mní, že bozi kdesi v nebesích/si nad tou krví mlsně ruce mnou“21) i smíchem jako životním postojem, projevem životní moudrosti (,smích ze všeho, smích, moudrost nejvyšši / a života to moudrost posledni'“22).

V básni Večer Marka Aurelia ve Vindoboně (Jed z Judey) Machar otevírá i otázku posmrtného života a objasňuje z pozic stoicismu, proč není třeba se smrti bát: „Nač se báti skonu? Zda zmizím v harmonii nekonečna / či znovu ožiji co květ, co ptáče — / dnes lhostejno je, jako potom bude / dojista lepším to, co přijde potom ${ }^{\prime 23}$.

Machar se svými verši pokusil o navržení nového axiologického systému (nelze hovořit o náboženství ani o filozofické koncepci), opírajícího se zejména o antickou tradici (jak již bylo zmíněno, nejvyšší ctností by měla opět být virtus). Nelze přehlédnout, že Macharovo volání po revizi hodnot pramenilo ze zklamaného křest’anství. Vážil si osobnosti Ježíše, jeho zvěst mu znevěrohodnili až Je-

19 J. S. Machar, Jed z Judey, Praha 1906, s. 52.

${ }^{20}$ J. S. Machar, $V$ záríi..., s. 154.

${ }^{21}$ Ibidem, s. 155.

22 Ibidem.

23 J. S. Machar, Jed..., s. 134. 
žíšovi následovníci a vykladači, zejména Pavel z Tarsu. V Jedu z Judey v básni Imperator Augustus Flavius Claudius Julianus čteme verše: „Rád bych byl býval na světě žil tenkrát, / když tesařův syn chodil po Judei, / rád bych byl jednou pohleděl mu v oči, / a slyšel slova jdoucí ze rtů jeho - / Vím, čím je dnes... rád znal bych, čím byl tenkrát!“24 A v Konfesích literáta vzpomíná, že jako dítě „měl rád Pána Ježíše fanatickou láskou“ 25 — absence výhrad vůči Ježíšově osobnosti mohla být dána i jistou nedotknutelností dětských mýtů a náboženských představ.

Počátek 20. století, kdy vyšly první Macharovy svazky cyklu Svědomím věkü, je možno vnímat v kontextu snah oslovit nábožensky moderního člověka, konfrontovat křest’anskou tradici s vědeckými poznatky (v této souvislosti je třeba připomenout Masarykův text z roku 1904 V boji o náboženství, zdůrazňující vědecké poznání), iniciovat změny uvnitř katolické církve. Machar této nabídce neodolal a využil k tomu svou pozici básníka. Nepřišel ovšem s ničím originálním, ale jen se zahořklým zklamáním z lidské neschopnosti dostát ideálům, které ho přivedlo $\mathrm{k}$ nenávistným invektivám vůči křestanům všech epoch a nepř́lišs kritickému pohledu na antiku.

\section{Bibliografie}

Dějiny české literatury III, ed. M. Pohorský, Praha 1961.

Heftrich U., Nietzsche v Čechách, přel. V. Koubová, Praha 1999.

Krejčí F. V., Nietzsche, „Rozhledy“ 1900, č. 1.

Machar J. S., Confiteor, Praha 1887.

Machar J. S., Jed z Judey, Praha 1906.

Machar J. S., Konfese literáta, Praha 1984.

Machar J. S., Magdalena, Praha 1894, 1926.

Machar J. S., Tríicet rokì, Praha 1919.

Machar J. S., Zde by měly kvést růže, Praha 1894, 2012.

Masaryk T. G., V boji o náboženství, Praha 1947.

Machar J. S., V záři helénského slunce, Praha 1906, 1912.

Machar J. S., Zde by měly kvést růže, Praha 2012

Novák A., Bedřich Nietzsche v Čechách, „Národní listy” 21.4.1912.

Pešat Z., J. S. Machar básnik, Praha 1959.

Stiebitz F., Macharova antika, „Naše věda” 1934, č. 9 (15).

Svoboda K., Antika a česká vzdělanost, Praha 1957.

Zouhar J., K rozšíreni Nietzschovy filozofie u nás na přelomu století, [in:] Sborník praci filozofické fakulty brněnské univerzity, B 39, Masarykova univerzita, Brno 1992.

24 J. S. Machar, Vzáři..., s. 187.

25 J. S. Machar, Konfese literáta, Praha 1984, s. 24. 


\section{Imagination of death in the poetic texts of Josef Svatopluk Machar}

\section{Summary}

The study deals with the theme of death in the poetry of J. S. Machar. There are two forms of death: death as a proud alternative to life and death as a concept of historicizing poetry. The beginnings of the 20th century, when Machar's first volumes of the cycle Svědomím věkü were published, can be viewed in the context of efforts of a religiously modern man, confronting the Christian tradition with scientific knowledge. Machar, with his verses, attempted to design a new axiological system, based in particular on the ancient tradition (the highest virtue was virtus). It cannot be overlooked that Machar's call for a revision of values stemmed from a disappointment in Christianity. He valued the personality of Jesus, according to Machar his message has been changed by the followers and interpreters of Jesus, especially Paul of Tarsus.

Keywords: Josef Svatopluk Machar, Czech poetry, blasphemy, 19th century, reception of the classical antiquity

\section{Wyobrażenia śmierci w tekstach poetyckich Josefa Svatopluka Machara}

\section{Streszczenie}

Artykuł został poświęcony analizie wątku śmierci w twórczości poetyckiej Josefa Svatopluka Machara. Wskazano dwa wizerunki śmierci: śmierć jako dumną alternatywę niewolniczego życia oraz śmierć jako koncept poezji historyzującej. Początek XX wieku, kiedy zostały opublikowane pierwsze tomy cyklu Svědomím věků autorstwa Machara, można postrzegać w kontekście formułowania się pytań religijnych wynikających z doświadczenia człowieka współczesnego, a także konfrontowania tradycji chrześcijańskiej z odkryciami nauki. W swoich wierszach Machar próbował zaproponować nowy system aksjologiczny, opierający się przede wszystkim na tradycji antycznej (najwyższą cnotą była virtus). Nie należy przy tym zapominać, że źródłem apelu Machara o redefinicję wartości było rozczarowanie chrześcijaństwem. Machar szanował postać Jezusa, uważał jednak, że jego przekaz zdyskredytowali jego naśladowcy i interpretatorzy, szczególnie Paweł z Tarsu.

Słowa kluczowe: Josef Svatopluk Machar, poezja czeska, bluźnierstwo, XIX wiek, recepcja klasycznego antyku 